DOI: http://dx.doi.org/10.33846/hn30505

http://heanoti.com/index.php/hn

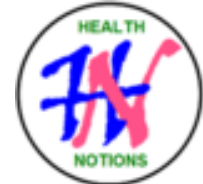

RESEARCH ARTICLE

URL of this article: http://heanoti.com/index.php/hn/article/view/hn30505

\title{
Development of Appropriate Technology for Utilizing The Effluent of Biogas Digester for Making Compost
}

\author{
Susi Nurweni ${ }^{1(\mathrm{CA})}$, Aries Presetyo ${ }^{2}$, Beny Suyanto ${ }^{3}$ \\ ${ }^{1(\mathrm{CA})}$ Departement of Environmental Health, Poltekkes Kemenkes Surabaya, Indonesia; \\ susinurweni@gmail.com (Corresponding Author) \\ ${ }^{2}$ Department of Environmental Health, Poltekkes Kemenkes Surabaya, Indonesia; arewinderika@gmail.com \\ ${ }^{3}$ Department of Environmental Health, Poltekkes Kemenkes Surabaya, Indonesia;benssuy@ gmail.com
}

\begin{abstract}
Effluent digester is potential to be composted by adding organic material (organic waste, etc.) and to accelerate maturity, inoculant effective Microorganism (EM) is required as bio decomposer in fermentation. Not only to break the chain of diseases, this organic fertilizer also economic value, sold as agricultural fertilizer.The purpose of this study is to use the effluent of biogas digester for making compost. This experimental research method using a randomized design consisting of 4 formulations each treatment replicated 3 times with 30 days maturation and the compost will be carried out physical and chemical assessment. The results showed that compost with biogas effluent material: charcoal secam: sequential organic waste with a ratio of formulas: 1 (4: 1: 1); $2(3: 1: 1) ; 3(2: 1: 1)$ and $4(1: 1: 1)$. Physical assessment of the 4 formulas, namely temperature, $\mathrm{pH}$, humidity, color, odor and texture meet the requirements of SNI 19-7030-2004. Measurement of the chemical content of formula 1 (content $\mathrm{C}: 14.36 \% ; \mathrm{N}: 0.98 ; \mathrm{P}: 1.27 ; \mathrm{K}: 1.11 ; \mathrm{C} / \mathrm{N}$ ratio: 14.78 ); 2 (content C: $17.85 \% ; \mathrm{N}$ : 2.06; P: 1.21; K: 0.88; C/N ratio: 16.91); 3 (content $\mathrm{C}: 16.14 \% ; \mathrm{N}: 0.84 ; \mathrm{P}: 1.02 ; \mathrm{K}: 1.10 ; \mathrm{C} / \mathrm{N}$ ratio: 14.78 ); 4 (content $\mathrm{C}: 16.42 \% ; \mathrm{N}: 0.89 ; \mathrm{P}: 1.15 ; \mathrm{K}: 0.88 ; \mathrm{C} / \mathrm{N}$ ratio: 18.52). The more use of biogas effluent produced compost with $\mathrm{N}, \mathrm{P}, \mathrm{K}$ the greater is followed by a decrease in $\mathrm{C} / \mathrm{N}$ ratio and met the requirements of SNI 197030-2004. The results of this study can be implemented by, from and for the community, in making compost that is economically beneficial, can reduce the expenditure of chemical fertilizers. renewable energy substitutes for LPG easily and at relatively low costs.
\end{abstract}

Keywords: appropriate technology; biogas digester effluent; compost

\section{INTRODUCTION}

\section{Background}

The process of composting can run aerobically and anaerobically which support each other in certain environmental conditions and this process is called decomposition ${ }^{(1)}$. To make this fertilizer needs inoculant material to change microorganisms in the soil. Effective Microorganism (EM) as bio decomposers are often used for fermenting organic materials. Compost with cow manure activator and commercial organic fertilizer take a longer decomposition process (40 days) and use EM4 activators 20 days faster ${ }^{(2)}$. The longer the decomposition process of the $\mathrm{C} / \mathrm{N}$ ratio decreases, the more opportunities for microorganisms to decompose compost material. The greater the $\mathrm{EM}_{4}$ concentration, the more number of bacteria found, so that the material decomposes faster by these bacteria ${ }^{(3)}$. Compost can be useful to reduce the amount of organic waste besides it 
is also safe because of breaking the chain of disease and has economic value as it can be sold as agricultural fertilizer $^{(4)}$.

Appropriate technology for making biogas from cow manure that produces renewable energy substitutes for LPG in the district of Parang, Magetan Regency is 20 units. But it also produces biogas effluent waste which is a slightly smelly liquid waste that has not been used properly and has an abundant amount. The addition of $2 \%$ bio inoculant $\mathrm{EM}_{4}$ at the beginning of the process in the digester can produce biogas for 17 days and from that day on, the biogas can be used to cover daily needs of cooking ${ }^{(5)}$. Based on the fact above, the experiment of the development of appropriate technology to use the effluent of biogas digester for composting is needed.

Development of Appropriate Technology for Utilizing the Effluent of Biogas Digester for Making Compost according to SNI 19-7030-2004. The benefit of this research is expected to be applicable to the community and reduce the use of chemical fertilizers.

\section{Purpose}

The purpose of this study is to use the effluent of biogas digester for making compost. This experimental research method using a randomized design consisting of 4 formulations each treatment replicated 3 times with 30 days maturation and the compost will be carried out physical and chemical assessment.

\section{METHODS}

This type of experimental research was conducted by making biogas effluent into compost. Research design was a One-shot case study, in which researchers conduct experiments using a randomized design consisting of 4 compost formulations which are treated, namely biogas effluent: husk charcoal: organic waste with a consecutively ratio of formulas: A $(4: 1: 1)$; B (3:1:1); C $(2: 1: 1)$ and D $(1: 1: 1)$. Each treatment was replicated 3 times to get 12 samples. Comparison of ingredients based on the weight of the material used. To speed up the composting process, an additional $2 \% \mathrm{EM}_{4}$ (effective microorganism) is used for each formula. Physical evaluation of compost maturation results: odor, color, texture, $\mathrm{pH}$, temperature; whereas chemistry results of laboratory tests N, P, K, C / N ratio. The content of the nutrient refers to 70/Permentan / Sr. 140 / 2011 or SNI 19-7030-2004.

1. Procedures:

a. Organic waste for about $50 \mathrm{~kg}$ is chopped on a cutting machine (cutter box copper) to get a smaller size $(1$ to $3 \mathrm{~cm})$

b. Mix thoroughly the ingredients: biogas effluent (4 kg), husk charcoal $(1 \mathrm{~kg})$, organic waste $(1 \mathrm{~kg})$ and EM4 (2\%). This method is named as Formula A

c. Then, put the ingredients into the digester (composting bath).

d. After 3 days, check the temperature and humidity, a good temperature has a maximum of $30^{\circ} \mathrm{C}$ heat and a maximum humidity is $50 \% \mathrm{RH}$, if the temperature and the humidity are more than that, it should be got reversed and water addition if needed.

e. Reversal is done several times until it is no longer hot.

f. After 4 weeks it is done and ready for use.

g. Take samples to examine the content of N, P, K, C / N ratio.

h. Repeat the procedure for formula B (biogas effluent $(3 \mathrm{~kg})$, husk charcoal $(1 \mathrm{~kg})$, organic waste $(1 \mathrm{~kg})$ and $\mathrm{EM}_{4}(2 \%)$, formula $\mathrm{C}$ : biogas effluent $(2 \mathrm{~kg})$, husk charcoal $(1 \mathrm{~kg})$, organic waste $(1 \mathrm{~kg})$ and $\mathrm{EM}_{4}$ (2\%); Formula D: biogas effluent $(1 \mathrm{~kg})$, husk charcoal $(1 \mathrm{~kg})$, organic waste $(1 \mathrm{~kg})$ and $\mathrm{EM}_{4}(2 \%)$.

2. Examine the Physical Quality of Compost

Compost is known to be mature if it fulfils the following requirements:

a. The color is dark brown to black similar to the color of the soil

b. The stack temperature decreases close to room temperature

c. Having good effect if applied to the soil

d. Does not stink, Ideal moisture, wet when being touched but is not watery when being squeezed

3. Test the Chemical Quality of Compost

To find out the chemical quality of compost, it can be done by laboratory testing of several chemical parameters of compost and its quality requirements in accordance with Regulation No. 70/2011, among others: Nitrogen $(\mathrm{N})$ levels of at least $0.40 \%$; Phosphorus $\left(\mathrm{P}_{2} \mathrm{O}_{5}\right)$ of at least $0.10 \%$; Potassium content $\left(\mathrm{K}_{2} \mathrm{O}\right)$ of at least $0.20 \%$; $\mathrm{C} / \mathrm{N}$ ratio between $10-20$. 
4. Data Collection Techniques and Data Analysis

Data collection was carried out by Observation and Laboratory Examination. Compost sampling in the fermentation process at 30 days to examine the level of NPK and C/N ratio. Data from laboratory results are processed manually and presented in table form.

\section{RESULTS}

Physical measurements of compost ( $\mathrm{pH}$, temperature, humidity, color, odor, texture) and chemistry $(\mathrm{C}$; $\mathrm{N}$; $\mathrm{P}$; K ; $\mathrm{C} / \mathrm{N}$ ) with 4 compost formulas up to 30 days as follows:

Table 1. Recapitulation of the results of chemical and physical measurements of compost

\begin{tabular}{|c|c|c|c|c|c|c|c|c|c|c|}
\hline \multirow[t]{2}{*}{ Formula } & \multicolumn{5}{|c|}{ Formula Physical parameters (average) } & \multicolumn{5}{|c|}{ Chemical parameters (average) } \\
\hline & $\begin{array}{l}\text { Tempera- } \\
\text { ture }\end{array}$ & $\mathrm{pH}$ & Humidity & Color & Odor Texture & $\mathrm{C}$ & $\mathrm{N}$ & $\mathrm{P}$ & $\mathrm{K}$ & $\mathrm{C} / \mathrm{N}$ \\
\hline $\begin{array}{l}\text { Efluent biogas, } \\
\text { household } \\
\text { garbage, husk } \\
\text { charcoal ( } 4: 1: 1)\end{array}$ & 30.7 & 6,9 & 51.2 & $\begin{array}{l}\text { Colour } \\
\text { similar } \\
\text { to soil }\end{array}$ & $\begin{array}{l}\text { Smell Tender } \\
\text { of soil and soft }\end{array}$ & 14.36 & 0.98 & 1.27 & 1.11 & 14.78 \\
\hline $\begin{array}{l}\text { Efluent biogas, } \\
\text { household } \\
\text { garbage, husk } \\
\text { charcoal (3:1:1) }\end{array}$ & 30.5 & 6,9 & 50.5 & $\begin{array}{l}\text { Colour } \\
\text { similar } \\
\text { to soil }\end{array}$ & $\begin{array}{l}\text { Smell Tender } \\
\text { of soil and soft }\end{array}$ & 17.85 & 1.06 & 1.21 & 0.88 & 16.91 \\
\hline $\begin{array}{l}\text { Efluent biogas, } \\
\text { household } \\
\text { garbage, husk } \\
\text { charcoal (2:1:1) }\end{array}$ & 30.7 & 6,9 & 47.3 & $\begin{array}{l}\text { Colour } \\
\text { similar } \\
\text { to soil }\end{array}$ & $\begin{array}{l}\text { Smell Tender } \\
\text { of soil and soft }\end{array}$ & 16.14 & 0.84 & 1.02 & 1.10 & 17.83 \\
\hline $\begin{array}{l}\text { Efluent biogas, } \\
\text { household } \\
\text { garbage, husk } \\
\text { charcoal }(1: 1: 1)\end{array}$ & 30.9 & 6,9 & 48.8 & $\begin{array}{l}\text { Colour } \\
\text { similar } \\
\text { to soil }\end{array}$ & $\begin{array}{l}\text { Smell Tender } \\
\text { of soil and soft }\end{array}$ & 16.42 & 0.89 & 1.15 & 0.88 & 18.52 \\
\hline
\end{tabular}

Description: Waste not using biogas effluent (Control) is not checked because physically it is still not done\& and smelly (fermentation)

Source: Chemical lab and soil fertility, soil science study department, UNS.2017 


\section{DISCUSSION}

Compost raw material is taken from Pasar Sayur on Jl. Mayjend Sungkono Magetan Regency and the campus of D3 Magetan Environmental Health Program in the form of vegetable waste, grass, sengon leaves, mango, tiara payung and other shrubs every day. The ash from the village's brick-making home industry belotan kec. Bendo, the biogas effluent comes from the village of Pragak Kec. Parang (D3 Magetan Environmental Health Study Program fostered community). There are 20 biogas units that produce 60 - 80 lt/day per biogas unit. Tools used is mechanical cutting box copper. It is a tool that is used to cut organic waste in order to obtain pieces less than $3 \mathrm{~cm}$ and can simplify, accelerate the composting process.

The result of this study was composting by physical and chemical observation.

\section{Observation of Temperature, $\mathrm{pH}$ and Humidity}

\section{$\underline{\text { Temperature }}$}

Based on the results of temperature measurements in Table 1, changes in the existing temperature occur between $28^{\circ} \mathrm{C}-40^{\circ} \mathrm{C}$. The initial temperature is $28^{\circ} \mathrm{C}$ at the beginning of the process, then slowly rises at the end of the first week and the beginning of the second week. Afterwards, the temperature decreases to around 30$35^{\circ} \mathrm{C}$ until the compost is mature. According to SNI 2004, the conditions for mature compost must have ground water temperature because this can be absorbed by plant roots in an aerobic atmosphere and not more than $30^{\circ} \mathrm{C}$. From the 4 (formula) treatments, there is no significant difference. Because it is controlled by reversing compost for 3 to 4 days so the temperature would not be more than $45^{\circ} \mathrm{C}$ and the fermentation process will run quickly.

The raw material for biogas waste in the form of a soft solution is predicted containing microorganisms which also help the fermentation process so that it can accelerate the compost maturity. To reduce the temperature to be optimal during the compost maturity process, it is done by turning the compost material back and forth.

According to Zaman \& Sutrisno, the compost temperature is mesophilic in the first 6 days then the thermophilic stage in the second 10 days $\left(46-56^{\circ} \mathrm{C}\right)$ and after the 18th day returns to the mesophilic stage which is characterized by a decrease in temperature towards the temperature stable ${ }^{(7)}$. This is in line with this study even though the raw material for compost is different but the first week the temperature increase up to the second week and then there is a decrease in temperature to around $30^{\circ} \mathrm{C}$.

According to Wellang, decomposer microorganisms will be active in the optimal temperature range of $30-60^{\circ} \mathrm{C}$ fast composting process. Too low temperatures and too high one can cause decomposer microorganisms inactive so that the composting process will not be perfect. Therefore, during the composting process it is necessary to pay attention to the temperature fluctuations. The existence of high temperatures in the composting process will kill pathogenic bacteria and weed seeds, besides, to accelerate the composting process, because the composting process generally takes place in a combination of thermophilic and mesophilic temperatures $^{(8)}$.

Humidity

The results of measurements of humidity from Table 1 can be seen that changes in humidity occurs from 40-60\% RH (2004 SNI maximum 50\% RH). This condition can be achieved at the age of compost at week 3. This is in line with the research SuyantoBeny, Prijono s, 2016 that compost maturity comes after week 3. The way to keep it moisture is by controlling compost ${ }^{(5)}$. Every 3 days, if too humid, it needs to be reversed until the optimum conditions. If too dry, it is necessary to spray water slowly until optimum moisture is reached. This is in line with Rahmawati ${ }^{(9)}$ the optimum range of microbial humidity accelerates the production of organic fertilizers made of the household waste because the availability of oxygen for aerobic microorganism activity causes rapid decomposition. However, if the water content is more than $60 \%$, it will cause an anaerobic condition. Thus, aerobic microorganisms cannot function and result in incomplete or slow composting processes. Some processes will turn to an aerobic and produce $\mathrm{CO}_{2}$ and organic compounds, such as organic acids and often cause foul odors. In order not to lack oxygen, usually a stack of materials is reversed or treated by using a blower. Material reversal is done at least once a week 
$\underline{\text { Degree of Acidity }(\mathrm{pH})}$

The acidity degree of the $\mathrm{pH}$ of this study is 6.8-7.1. (table 1: average 6.9) and meets SNI/2004 requirements about compost quality standards (6.8-7.49) Compost $\mathrm{pH}$ measurements are carried out every 3 days to find out whether the composting process is running well. Changes in odor, color and texture of organic matter in this compost experiment can be affected by $\mathrm{pH}$ changes. The increase of $\mathrm{pH}$ indicates that a number of bacteria reuse organic acids as a source of energy. All of the formulas in the study has the average of $\mathrm{pH}$ : 6.9 and do not show a significant $\mathrm{pH}$ difference. The former low $\mathrm{pH}$ values will rise slowly and will be constant after 3 weeks of treatment.

According to Polpraset changes in $\mathrm{pH}$ occur the process of decomposition of complex and reactive organic materials such as sugar, flour, carbohydrates, fat into simple organic acids. After that, on the 10th day the $\mathrm{pH}$ of materials stack will increase, that change them to alkaline. This is because simple organic acids formed in the initial decomposition are converted to methane and $\mathrm{CO} 2$ by the bacteria forming the methane. After increasing up to the highest point of all variations of the compost pile showing almost the same behavior and until the end of the composting process the $\mathrm{pH}$ value is still fluctuating but still within the acceptable range $(7-7.8){ }^{(10)}$

To reach the optimum process of composting plus EM4 ranging from 6,5 to 7,5 will cause changes in campus waste and the $\mathrm{pH}$ of the material itself. $\mathrm{pH}$ is around 6,0 on the first day, but for the following day $\mathrm{pH}$ begins to rise and changes to stable condition preventing the acidity of compost ${ }^{(5)}$. The degree of acidity $(\mathrm{pH})$ is one of the factors supporting compost maturity, $\mathrm{pH}$ must be maintained in the normal range to minimize the loss of nitrogen in the formation of ammonia gas. The production of ammonia from nitrogen-containing compounds will increase $\mathrm{pH}$ in the initial phase of composting and if the compost is mature, it is usually close to neutral ${ }^{(7)}$.

\section{The Results of Physical Observations of Color, Smell and Texture}

Color

The observation of the color of compost in the first week is still almost the same as the color of the original condition. From the 4 formulas, it is the beginning of the fermentation process. But at the end of the week it seems to be getting brownish tend to be darker. The color looks different at the age of 3-4 weeks decomposition process of compost and changes blackish soil color.

The changes in color during the fermentation process indicating the presence of decomposers of microorganisms which works well. Another influential factor is also because the treatment to control temperature and humidity during the process. This is in line with the research of Kusuma, the more working microbial decomposers in compost will accelerate composting so that color changes become blackish. ${ }^{(11)}$

These condition is in accordance with the Minister of Agriculture Regulation No. 70/2010 and / or SNI / 2004 and is ready to be used for composting plants. In terms of color it is very difficult to distinguish from 4 formulas for 30 days because it is almost the same. While the color of the control compost is almost the same as the original color and only looks more brownish dry leaf color. ${ }^{(12)}$

According to Widiyaningrum \& Lisdiana, the color of compost that has become blackish soil either using $\mathrm{EM}_{4}$ or MOL on leaf compost and goat droppings at different ages. Compost using $\mathrm{EM}_{4}$ is changing the color to blackish soil faster than those using MOL because the number of fermentor bacteria from EM4 is more complete than the MOL bacteria used. ${ }^{(13)}$

$\underline{\text { Smell }}$

The observation of compost odor for up to 2 weeks shows a distinctive odor of fermentation, while that of more than 3 weeks smells of soil (according to SNI / 2014 and permentan: 70/2010) ${ }^{(12)}$ and is difficult to distinguish between each formula. Approaching the maturity, the compost smells more like soil ${ }^{(8)}$. According to Widiyaningrum \& Lisdiana, making compost from leaves and goat droppings using $\mathrm{EM}_{4}$ does not smell up to 6 weeks of fermentation. ${ }^{(13)}$ Making compost from organic matter (leaves) which is finely chopped $(1-3 \mathrm{~cm})$ and adding $\mathrm{EM}_{4} 2 \%$ requires 21 days of maturation ${ }^{(5)}$. 
Texture

The texture during process of composting up to 2 weeks slightly changed from the base material. But approaching 3 weeks process, the texture becomes smoother than each formula. There is a slight physical difference in texture, that is the more uses of biogas effluent tend to be more tender texture. This is predicted because the material used in this study comes from the same location even though the process of giving biogas effluent was different. So there is a relationship that is getting closer to the compost maturation, the texture becomes smoother and the more biogas effluent used, the smoother the texture will be. While the texture of the control compost up to 30 days is still similar to the original texture, still rough and there has been no change.

The conditions mentioned above are supported by research by Wellang ${ }^{(8)}$ and Kusuma ${ }^{(11)}$ that to produce organic fertilizers successfully, it is necessary to pay attention to the texture and arrangement of raw materials that the smaller pieces of raw material is, the faster decay process will be. Compost texture that has become smooth and moist at the age of 6 weeks is influenced by $\mathrm{EM}_{4}$ fermentor microorganisms namely photosynthetic bacteria, Lactobacilus $S p$, Streptomyceters $S p$, yeast and Actinomycetes ${ }^{(10)}$.

\section{Results of Measurement of Chemical Parameters}

Compost of 4 formulas in this study measured chemical parameters $\mathrm{C}, \mathrm{N}, \mathrm{P}, \mathrm{K}$ and $\mathrm{C} / \mathrm{N}$ with reference to SNI / 2004 and PERMENTAN 70/2010 ${ }^{(12)}$ with the following results:

Nitrogen $(\mathrm{N})$

Laboratory tests for Nitrogen $(\mathrm{N})$ parameters in all 30 days of the 4 formulas fulfills the 2004 SNI requirements $(>0.4 \%)$, ie $0.84-1.06 \%$ (table 1$)$. There is a tendency that the use of biogas effluent will increase the amount of $\mathrm{N}$ content. The $\mathrm{N}$ element of the biogas effluent is $0.1 \%^{(14)}$ mixed with organic garbage material and husk charcoal with a ratio of 3: 1: 1 produces the highest compost $\mathrm{N}$ element compared to the formula with a ratio of $4: 1: 1 ; 2: 1: 1$ and 1: $1: 1$. It can be concluded that effluent biogas can be used if we want to produce compost with great $\mathrm{N}$ element. Biogas waste can increase agricultural production due to the nutrient content, enzymes and growth hormones contained therein ${ }^{(15)}$.

Nitrogen is one of the important parameters that must be present in compost, because nitrogen is needed to compile $1-4 \%$ of dry matter (hard parts) of plants, such as stems, skin, and seeds. Nitrogen is taken from the soil in the form of nitrate $\left(\mathrm{NO}^{-}\right)$or ammonium $\left(\mathrm{NH}^{+}\right)$, or in combination with carbohydrate metabolic compounds in plants in the form of amino acids and proteins. Nitrogen is also available in small amounts of compost and manure ${ }^{(8)}$. Nitrogen is needed in relatively large quantities at each stage of plant growth. Nitrogen can return to the soil through decayed living material (organic matter). Nitrogen which is derived from these organic materials can be utilized by plants after going through three stages of reaction involving soil microorganism activity ${ }^{(16)}$.

In composting there is a breakdown of carbohydrates in the form of hemicellulose into $\mathrm{CO} 2$ and $\mathrm{H} 2 \mathrm{O}$ or $\mathrm{CH} 4$ and $\mathrm{H} 3$, the protein will break down into amides and amino acids which are then converted into $\mathrm{NH} 3, \mathrm{CO} 2$ and $\mathrm{H} 2 \mathrm{O}$. Mineral nutrients from organic compounds break down into available inorganic materials in the form of ions namely $\mathrm{NH} 4, \mathrm{NO} 2$ and $\mathrm{NO} 3$ ions $^{(17)}$.

$\underline{\text { Phospor (P205) }}$

Based on table 1, the results of laboratory tests on Phospor parameters $\left(\mathrm{P}_{2} 0_{5}\right)$ averaged 1.02 to $1.27 \%$ for the 30-day maturation process. Making organic fertilizer in formula 1 (biogas effluent: organic waste: husk charcoal $=4: 1: 1$ ) the result is $1.27 \%$ compared to formula 4 (biogas effluent: organic waste: husk charcoal $=1$ : 1: 1) yield $1,15 \%$. This shows that there are indications that the more biogas effluent used in this study will increase the Phospor content $\left(\mathrm{P}_{2} \mathrm{O}_{5}\right)$. The smaller $\mathrm{C} / \mathrm{N}$ will produce greater Phospor $\left(\mathrm{P}_{2} \mathrm{O}_{5}\right)$. Thus the more biogas effluent, the value of the $\mathrm{C} / \mathrm{N}$ ratio decreases and will increase Phospor $\left(\mathrm{P}_{2} \mathrm{O}_{5}\right)$. This concentration exceeds SNI-2004, meaning that it meets the requirements with the Phospor $\left(\mathrm{P}_{2} \mathrm{O}_{5}\right)$ quality standard of at least $0.10 \%$. Biogas waste is rich in nutrients such as nitrogen, phosphorus and other valuable organic materials ${ }^{(18)}$.

$\mathrm{P}$ element is an important element in compost, because this element is the main nutrient for plant growth. The content of $\mathrm{P}$ elements is higher with the weathering of composted organic matter. At the maturation stage the microorganism will die and the $\mathrm{P}$ content in the microorganism will mix in the compost material which will directly increase the Phospor content (P205) in $\operatorname{compost}^{(8)}$. 


\section{$\underline{\operatorname{Potassium}\left(\mathrm{K}_{2} \mathrm{O}\right)}$}

Laboratory results of Potassium $\left(\mathrm{K}_{2} \mathrm{O}\right)$ parameters using formula 1, namely biogas effluent: organic garbage : husk charcoal $=4: 1: 1$ produced the highest potassium $\left(\mathrm{K}_{2} \mathrm{O}\right)$ content $(1.11 \%)$ greater than 3 other formulas (fulfilling SNI-2004 standard which is minimum of $0.20 \%$ ). Thus it can be concluded that if you want a large amount of Potassium $\left(\mathrm{K}_{2} \mathrm{O}\right)$ content you need to use the greater biogas effluent material. Effluent biogas which still contains EM in improving the maturity and potassium $\left(\mathrm{K}_{2} \mathrm{O}\right)$ process. Increased potassium content was followed by the decrease in $\mathrm{C} / \mathrm{N}$ ratio. This shows the activity of microorganisms using potassium (K) as a catalyst in the fermentation process. The condition is supported by research by Yuniwati, et al., namely the greater the use of $\mathrm{EM}_{4}$, the faster the decline in $\mathrm{C} / \mathrm{N}$ ratio and the shorter composting time will be. ${ }^{(3)}$

\section{$\underline{\text { Carbon Content }(\mathrm{C})}$}

The results of measuring $C$ levels in formula $1 ; 2 ; 3$ and 4 respectively $=14.36 ; 17.85 ; 16.14$ and $16.42 \%$. This content fulfils the requirements of SNI 19-7030-2004, namely 9.8 - 32\%. The utilization of biogas effluent from the formula mentioned above shows that microorganisms from biogas effluent are still mixed in the process of compost maturation. The combustion reaction of carbon and oxygen elements can be used as energy by microorganisms, while the decomposed nitrogen elements are utilized by microorganisms to build the cells of these microorganisms. Organic $\mathrm{C}$ content is one indicator of the quality of organic fertilizer because it can improve the properties and structure of soil and increase its capacity to store water ${ }^{(19)}$.

Whereas Ratrinia et al., the addition of $\mathrm{EM}_{4}$ in the composting process will accelerate the process because the more microorganisms increase, the higher the process of fermentation of waste is processed will be. In the composting process, the decomposition causes the carbohydrate levels to be lost or continue to fall and the dissolved $\mathrm{N}$ compounds increase. ${ }^{(20)}$

\section{$\underline{\text { Level of } \mathrm{C} / \mathrm{N} \text { ratio }}$}

The results of the measurement of $\mathrm{C} / \mathrm{N}$ ratio are $14.78-18.52 \%$. While the requirements of SNI 19-70302004 concerning compost quality standards are $10-20 \%$. The $\mathrm{C} / \mathrm{N}$ ratio is the ratio between carbohydrate (C) and nitrogen $(\mathrm{N})$. If the $\mathrm{C} / \mathrm{N}$ ratio is greater 20 indicates that $\mathrm{C}$ is incomplete oxidized to carbon dioxide $\left(\mathrm{CO}_{2}\right)$ and eliminated nitrogen. This shows that there is an effective role of microorganisms in biogas effluent on compost maturation. The greater $\mathrm{EM}_{4}$ concentration mentioned above will decrease the $\mathrm{C} / \mathrm{N}$ ratio ${ }^{(5)}$. This is reinforced by the results of the study of Mumi Yuniwati et al. that the greater the concentration of $\mathrm{EM}_{4}$, the faster the decline in the $\mathrm{C} / \mathrm{N}$ ratio and the shorter the process of compost maturation will be. This is because the greater the concentration of $\mathrm{EM}_{4}$, the greater the number of bacteria that break down the material so that the material decomposes faster by the bacteria. ${ }^{(3)}$

The $\mathrm{C} / \mathrm{N}$ ratio gives an idea of whether or not the material is weathered, the maturity level of the organic matter or $\mathrm{N}$ mobility in the soil, soils with stable organic matter generally have a $\mathrm{C} / \mathrm{N}$ ratio of around 10 . At the $\mathrm{C} / \mathrm{N}$ ratio, element $\mathrm{C}$ is used as energy for the life of microorganisms and $\mathrm{N}$ elements for protein synthesis. If the $\mathrm{C} / \mathrm{N}$ ratio is too high, microbes will lack $\mathrm{N}$ for protein synthesis so that decomposition runs slowly.

Generally, the main problem of composting is at high $\mathrm{C} / \mathrm{N}$ ratio, especially if the main ingredient is material containing high wood content (the remaining sawn timber, twigs, pulp, etc.). Generally, the organic materials provided has a high $\mathrm{C} / \mathrm{N}$ ratio, therefore a composting process is needed that aims to reduce the $\mathrm{C} / \mathrm{N}$ ratio. The process of decomposing organic matter with a high $\mathrm{C} / \mathrm{N}$ ratio will give an adverse effect on plants because it can cause on lack of nutrient availability - other nutrients decrease, such as nitrogen available in the soil. The high $\mathrm{C} / \mathrm{N}$ organic matter causes competition between plants and microbes, so the plants will run out of nitrogen supply.

\section{CONCLUSION}

The results of this study can be concluded that Kompos with biogas effluent raw material: husk charcoal : organic garbage by comparison (4:1:1); (3:1:1); $(2: 1: 1)$; (1:1:1) physically and chemically fulfills the requirements of SNI 19-7030-2004. The results of compost products with 30-day maturation fermentation process shows that the greater biogas effluent use is better both physically and chemically. 


\section{REFERENCES}

1. Yuwono. Compos (Kompos). Jakarta. Penebar Swadaya; 2015.

2. Rahmawanti N, Dony N. Making Organic Fertilizer Made from Household Organic Waste by Adding EM 4 Activator in the Tangi Kayu Area (Pembuatan Pupuk Organik Berbahan Sampah Organik Rumah Tangga dengan Penambahan Aktivator EM 4 di Daerah Kayu Tangi). Ziraa'ah Majalah Ilmiah Pertanian. 2014;39.

3. Yuniwati M. Optimizing the condition of the process of making compost from organic waste by fermentation using EM4 (Optimasi kondisi proses pembuatan kompos dari sampah organik dengan cara fermentasi menggunakan EM4). Jurnal Teknologi. 2012;5(2):172-181

4. Riyo S. Compost Fertilizer. Yogyakarta: Citra Aji Parama; 2010.

5. Nurweni S. Effective Technology for Effective Microorganisms (EM) Results of Bioinoculant Engineering to Increase the Quantity of Biogas. Competitive Grant Research. Surabaya: Poltekkes Kemenkes Surabaya; 2017.

6. Suyanto B, Prijono S. Design of tools for making organic fertilizers for campus and school. Competitive Grant Research. Surabaya: Poltekkes Kemenkes Surabaya; 2016.

7. Zaman B, Sutrisno E. Study of the Effect of Domestic Waste Mixing, Rice Husk, and Sugar Cane Using Mac Donald's Method on Compost Maturity. Semarang: Environmental Engineering Study Program, FTUNDIP; 2007.

8. Wellang RM. The feasibility study of compost using bioactivator variations (EM4 and yeast). Postgraduate Thesis. Makassar: Environmental Engineering Study Program, Hasanudin University; 2015.

9. Rachmawati N, Susilawati, Prihatiningtyas E. Processing Organic Waste Into Compost To Support Pro Climate Villages (Pengolahan Sampah Organik Menjadi Kompos Untuk Mendukung Kampung Pro Iklim). Jurnal Al-Ikhlas. 2019;4(2):124-132.

10. Polpraset, Chongkrak. Organic Waste Recycling Environment. Bangkok: Asian Institute of Technology; 1993.

11. Kusuma ME, Silitonga L. Pengaruh Lama Proses Pembuatan Pupuk Kompos Berbahan Limbah Kotoran Ternak Sapi Terhadap Kualitas Pupuk Kompos (The Effect long process of compost waste of livestock to the quality of compost). Jurnal Agri Peat. 2013;14(1).

12. Kementan RI. Regulation of the Minister of Agriculture No. 70 / Permentan / SR. 140 / 10/2011 concerning Organic Fertilizers, Biofertilizers and Soil Enhancers (Peraturan Menteri Pertanian Nomor 70/Permentan/SR.140/10/2011 Tentang Pupuk Organik, Pupuk Hayati Dan Pembenah Tanah). Jakarta: Kementan RI; 2010.

13. Widiyaningrum P, Lisdiana. Differences in physical and chemical composition of leaf compost using bioactivator MOL and EM4. Journal of Sainteknovol. 2013.

14. Karno, Koesmantoro H. Practical Guide: Making Biogas Easy and Cheap (Panduan Praktis: Membuat Biogas itu Mudah dan Murah). Ponorogo: Forum Ilmiah Kesehatan (FORIKES); 2013.

15. Karki KH. Response to Bio-Slurry Application on Maize and Cabbage in Lalitpur District. Final Report. Jakarta: Alternative Energy and Promotion Center, Ministry of Science and Technology of Republic of Indonesia; 2001.

16. Novizan. Instructions for Effective Fertilization. Jakarta: Agromedia Pustaka; 2007.

17. Pandebesie, Ellina. Waste Management Techniques. Surabaya: Institute; 2015.

18. Seleiman MFP, Makeela P, Santanen A, Stoddard F. Effect of Sludge and Germination and Growth of Bioenergy Crops. MaataloustieteenPäivät; 2012.

19. Krismawati A, Asnita R. Organic fertilizers from organic household waste. Sinar Tani. 2011;41(3417):2-11.

20. Ratrinia PW, Ma'ruf WF, Dewi EN. The Effect of Using Em4 Bioactivator And Addition of Leucaena Leucocephala Leaves To Eucheuma Spinosum Seaweed Organic Fertilizer Specifications (Pengaruh Penggunaan Bioaktivator Em4 Dan Penambahan Daun Lamtoro (Leucaena Leucocephala) Terhadap Spesifikasi Pupuk Organik Cair Rumput Laut Eucheuma Spinosum). 2014;3(3):82-87. 